\title{
Al-ZARNUJI'S THOUGHT OF EDUCATION AND ITS IMPLEMENTATION AT PESANTREN
}

\author{
Maslani \\ Universitas Islam Negeri (UIN) Sunan Gunung Djati Bandung \\ Jl. A. H. Nasution No. 105, Cibiru, Bandung, Jawa Barat, Indonesia 40614 \\ Email: maslani@uinsgd.ac.id

\section{Ratu Suntiah} \\ Universitas Islam Negeri (UIN) Sunan Gunung Djati Bandung \\ Jl. A. H. Nasution No. 105, Cibiru, Bandung, Jawa Barat, Indonesia 40614 \\ Email: ratusuntiah@uinsgd.ac.id

\section{Yasniwarti} \\ Universitas Islam Negeri (UIN) Sunan Gunung Djati Bandung \\ Jl. A. H. Nasution No. 105, Cibiru, Bandung, Jawa Barat, Indonesia 40614 \\ Email: yasniwartidjaluis@uinsgd.ac.id

\section{Dadan Nurulhaq} \\ Universitas Islam Negeri (UIN) Sunan Gunung Djati Bandung \\ Jl. A. H. Nasution No. 105, Cibiru, Bandung, Jawa Barat, Indonesia 40614 \\ Email:dadan@uinsgd.ac.id
}

Received: 04, 2017. Accepted: 12, 2017. Published: 12, 2017.

\begin{abstract}
The study aims to find out al-Zarnuij's basic concept of knowledge, learning material, ethic, strategy, process and his contribution as well as to explain conceptual model on the basis of his thought at the institutions. In Pesantren Kebon Jambu al-Islami, Buntet and Bendakerep Cirebon, the Kitab Ta'lim alMuta'allim is used as main reference of learning ethic. The study used qualitative research method. Source and kind of data were determined by the researcher as information center with purposive trait as long as it is supposedly representative. The result indicates that the implementation of the book Ta'lim alMuta'allim at those pesantrens was less satisfactory due to textual understanding. In order to effectively implement the book Ta'lim al-Muta'allim at those institutions, the contextual description is required.
\end{abstract}

Keywords: Al-Zarnuji, Learning, Pesantren, Ta'lim al-Muta'allim.

\begin{abstract}
ABSTRAK
Makalah ini bertujuan untuk mengkaji konsep dasar pengetabuan, materi, etika, strategi, proses pembelajaran dan kontribusi al-Zarnuji, serta untuk menjelaskan model konseptual berdasarkan pemikirannya di lembaga pendidikan Islam. Kitab Ta'lim al-Muta'allim digunakan di Pesantren Kebon Jambu al-Islami, Buntet dan Bendakerep Cirebon, sebagai rujukan pada pembelajaran akblak. Penelitian menggunakan metode penelitian kualitatif. Sumber dan jenis data ditentukan oleh peneliti sebagai pusat informasi dengan metoda purposif asalkan diduga mewakili. Hasil penelitian menunjukkan babwa penerapan kitab Ta'lim al-Muta'allim di pesantren tersebut kurang memuaskan karena pemahaman tekstual. Untuk menerapkan secara efektif kitab Ta'lim al-Muta'allim di lembaga tersebut, deskripsi kontekstual sangat diperlukan.
\end{abstract}

Kata Kunci: Al-Zarnuji, Pembelajaran, Pesantren, Kitab Ta’lim al-Muta'allim. 


\section{INTRODUCTION}

It goes without saying that in various pesantrens both traditional and modern, the book Ta'lim alMuta'allim is used as a main reference in moral or ethic learning. This book is so popular that almost every pesantren student knows the book. Many scholars have examined the book in various points of view. Huda \& Kartanegara (2015b) for example, have concluded that this book teaches three points: 1) the main goal of acquiring knowledge, it is classified as religious conservativebased ideology; 2) the basic concept of human character, it comes from a good interaction with a good environment; and 3) the importance of selecting good friends and teachers, this is done to produce good human character

In their subsequent paper, Huda and Kartanegara (2015a) explain that al-Zarnuji offers three formulations as the primary goal of education. First, to achieve Allah's approval; second, to guide each's development; and third, to possess the ability to interact socially. Huda et al. (2017) also explain that in the book Ta'lim al-Muta'allim it is firmly interpreted that education refers to a process of transferring knowledge and values simultaneously. Knowledge and value are two things that are inseparable in the learning process. The values resulting from the educational process are the values of Islamic character built on the basis of the Qur'an and hadith (Huda \& Kartanegara, 2015a). Furthermore, Huda et al. (2017) describe the book Ta'lim al-Muta'allim introduces the learning process with a holistic approach. Learning with a holistic approach will enable resilient learners to cope with learning barriers.

In a recent study of the ethical grounds for a teacher, Huda et al. (2017) explains that alZarnuji emphasizes on several key aspects, namely: 1) professional ability; 2) critical thinking; 3) commitment; 4) interactive manner while teaching; 5) ability to play emotions while teaching; and 5) full of experience. In the same vein, Akhyar (2008) reviewed the book Ta'lim al-Muta'allim from aspects of learning method. The results of his research mention that the methods contained in the book is still very relevant if used in today's learning, such as methods of discussion mudzäkarah, munādzarah, muthärahah. Also, the principles of education described in the book Ta'lim al-Muta'allim are still very relevant to be used as a reference by teachers and students to achieve educational goals (Miftahuddin, 2006).

In addition to previous research on the content and learning methods contained in the book Ta'lim al-Muta'allim, there is also a study investigating this book from the systematic aspects of writing the book and methods to study the book. The study was conducted by Ummah and Wajdi (2016). Their research explains how al-Zarnuji began the book Ta'lim al-Muta'allim and the division of each chapter. Similarly, this study informs how we should study each of the books.

From the above descriptions, it is known that there have been a lot of research done about the book Ta'lim al-Muta'allim. Nevertheless, there is always another side that has never been studied. This study, for example, seeks to look at another aspect of this book, which is the implementation of the book study of Ta'lim al-Muta'allim in Islamic educational institutions. Nowadays, there is a trend in our society that pesantren is enthusiastically integrating religious education with the secular one as a response of demand in society which is more developing. However, there are some improper tendencies with Islamic educational principles. Among them are as though education has lost its ethical message, education has turned its goal of human creation aside and only orients on specific demand. This situation creates a dilemma and leads to educational crisis. Therefore, it is requisite to research educational model at the pesantren specifically in Kebon Jambu al-Islami Babakan Ciwaringin, Buntet and Bendakerep Cirebon which is still using the book Ta'lim al-Muta'allim as reference of learning method and ethics up to present. Related to this, there appears a basic question to discuss. The question is: how those pesantrens comprehend and implement basic concept of learning, subject matter, ethic of learning, strategy of learning and the process of learning to build ethical education in those institutions? 
In the practice of teaching at the pesantren, the determination of a theoretical foundation for whole situation is less favorable measure. Because there is no single learning theory which is appropriate for entire situation. Each theory has distinct foundation and is usually compatible for certain situation. Therefore, the type of learning adhered on learning at the pesantren is the unity which means that it equips each other and it does not contradict each other.

Related to this, the focus of this research is the implementation of al-Zarnuji's educational thought on the education at Pesantren Kebon Jambu al-Islami, Buntet and Bendakerep Cirebon. In the end, this paper try to find out the conceptual model on the basis of al-Zarnuji's thought on the education at the Pesantren Kebon Jambu al-Islami, Buntet and Bendakerep Cirebon.

\section{METHOD}

This research used descriptive-qualitative method. To achieve the comprehensive and holistic reflection on learning at the Pesantren Kebon Jambu al-Islami Babakan Ciwaringin, Buntet and Bendakerep Cirebon, the researcher endeavors: 1) to take up the data from such situation; 2) to observe research setting and interview the informan in person; 3) to consider the process and event happened rather than the result or output attained; 4) to analize the data using inductive principle; 5) to interprete the data to comprehend the real situation; 6) to verify validity of data and information from the field and informan by matching them with data from other source.

The sequence of the research covered pre-observation, observation, intensively analytic action. In the implementation, pre-observation activity concerned with initial study of research setting, discussion of the book Ta'lim al-Muta'allim, literature study and compiling research design including the instruments of data collection. Observation, interview and documentation study were applied in the field activity. All collected data, then, were intensively and comprehensively analyzed and interpreted as well as concluded.

\section{RESULTS AND DISCUSSION \\ The Book Ta'lim al-Muta'allim}

Al-Zarnuji and Ismail (1995) with his monumental book, Ta'lim al-Muta'allim, is extremely popular in pesantrens. Moreover, this work becomes the gate for students to start learning. This book has been translated into various languages such as English, Urdu, Latin and Indonesian (Nakosteen, 1964). It is not precisely well-known who al-Zarnuji is. Plessner as quoted Sayyid Ahmad Utsman in Min 'Álam al-Tarbiyyah al-'Arabiyyah al-Islämiyyah, asserted that al-Zarnuji was an Arabian philosopher not definitely known who he actually was. It was confirmed by Sayyid Ahmad Utsman that al-Zarnuji was known as the follower of Hanafite persuasion. He was the student of al-Farwani al-Marwani. He roughly lived in the end of sixth century or in the beginning of the seventh century. He lived in Khurasan, a small city with good Islamic educational environment with Hanafite persuasion. Based on his familial relation, al-Zarnuji was probably from Zarandji, a town in Persia and Sijistan, a city in the southern part of Heart (now Afghanistan). There was not adequately significant information to be accurate data. Apart from this speculation, however, there was something undeniable that al-Zarnuji lived in the era when Islam had had its setback on government and thought.

The book Ta'lim al-Muta'allim generally contains three primary aspects of discussion. The first, it contains the basis of learning comprising: a) ilsämiyat al-ta'lim (learning obligation). Here, learning is an obligation and prevails all one's life; b) aghrädl al-ta'allum (learning goal). Each Moslem is obliged to master religious knowledge and apply it to worship well to God as the purpose. The second, it contains al-mawwäd al-dirasiyyah (learning materials ) covering: a) Ulüm fardl 'ain (primary knowledge). In this case, the material of religious application lesson is put into curriculum. It is dominated by knowledge such as fiqh (Islamic law), akhlak (moral) and tasawnf (mysticism); b) 'Ulüm fardl kifäyah (secondary knowledge) namely knowledge required to perfect 
one's life. The third, it contains learning method consisting of: a) learning ethics comprising alniyyah (intention) which is according to al-Zarnuji is learning principle and it becomes reference to guide and focus any activity to the purpose. To search for knowledge, it is not only by intention (al-niyyah) but also perseverance (al-jidd), resignation (al-tawakkul) and respect (al-burmab). Students must respect their parents, teachers, friends and erudite people surrounding them; b) learning strategy covering ikhtiyar al-ustädz. (selecting teacher). Al-Zarnuji quite spotlights the issue of educator a lot including the criteria of selected teacher. The characters of selected educator are more knowledgeable, more careful from committing a sin. Ikbtiyär al-syarik (selecting companion), Al-Zarnuji and Ismail (1995) affirms that students should be perceptive to this matter by selecting appropriate companions so that they are able to motivate to attain success in seeking knowledge. Tasyjì al-nafs (self-motivating), al-Zarnuji spotlights the issue of students in the term of motivation. He utters that students should choose good school and knowledge they like; c) learning process consisting of bidàyat al-sabq wa qadrib (time of learning). According to AlZarnuji and Ismail (1995), a good time to begin learning is Wednesday and the proper time to learn is baina al-isyaain (at the time to perform west prayer and evening prayer) and at the time prior to performing dawn prayer. Tadarruj fi al-tadris (stage of learning), it is suggested for the teacher to make lesson briefer and easier so that it can be understood and remembered easily. Basic learner is desirable to memorize the lesson very well. Tikerär al-durüs (reviewing lesson), after memorizing, students are suggested to be able to comprehend the lesson by reviewing each material taught. Al-Zarnuji reveals, memorizing two letters is better than hearing two lessons all at once and comprehending two letters is better than memorizing two lessons all at once. Daur al-ta'ämmul fi al-ta'lim (thinking process), mudzäkarah (changing one's mind), munäzharah (public debate) and mutharahah (forum of discussion) are implementation methods of discussion. Discussion is the most effective method because of its dialog and dialectic character. Al-Ta'lim al-Mutanawib (having apprentice), reflecting and rethinking to find the essence of knowledge. An appeal for having ability to reflect or actualize lessons taught is addressed to the students. Only by reflection, all matters can be solved. Nashäih li al-muta'allim (adjustment), Al-Zarnuji \& Ismail (1995) argues that students never hold on to their own belief and thought but it is desirable that they place their trust in God to search for the truth from Him. It means that an effort of seeking knowledge, prayer and resignation are pedagogical unity that should be held by every seeker of knowledge. Mu'taqadàtu 'ashrib (developing trust in its period) it is suggested that a learner not sweep in the evening, mop the floor with fabric, burn onionskin, wear trousers while sitting and wear turban while standing and many others.

\section{Implementation of Learning Based on Book Ta'lim al-Muta'allim at the Pesantren Kebon Jambu al-Islami Babakan Ciwaringin, Buntet and Bendakerep Cirebon}

From the educational practice at the three pesantrens, it was found a fact that learning concepts applied covered learning basis, subject matter, learning ethic, learning strategy and learning process. Based on the result of interview carried out at those institutions and fact observation in the field, it was known that the book Ta'lim al-Muta'allim became a guidebook to educate students. It was explained that: 1) the basis of learning in Ta'lim al-Muta'allim referred to Prophet Muhammad's words asserting that learning is obligation for each moslem and it was carried out during his lifetime; 2) kyais classified subject matter into two categories. The first is knowledge related to act of devotion in any kind of situation for each individual (Moslem). To learn this kind of knowledge is obligation for each moslem (fard 'ain). The second is knowledge concerning with issues affecting someone to certain reasons. To seek this knowledge is fard kifäyah (communal obligation); 3) kyais emphasized learning ethics on four matters namely intention (niyyah), perseverance (al-jid), resignation (al-tawakkul) and respect (al-burmab); 4) learning strategy applied covered four respects. They were selecting subject (ikbtiyār al-ilm), selecting teacher (ikhtiyār al-ustädz), selecting companion (ikhtiyär al-syarik) and self-motivating 
(tasyji al-nafs); 5) learning process carried out with kyais comprised bidayat al-sabq (time of learning). It was explained that the effective age to learn is in the young age and a good time to learn is between the time to perform west prayer and evening prayer and at the time prior to performing dawn prayer. When students had completed a lesson, they should move on other lesson. Tadarrij fi al-ta'lim (stage of learning), students should learn in stages from the simple lesson to the complex one. Tikrär al-durüs (reviewing lesson), students should learn repeatedly. Daur al-ta'ammul fi al-ta'lim (thinking process), students should carry out discussion with their companions, change one's mind and do debate. Debate is a kind of discussion and discussion is to gain the truth. Al-ta'lim al-mutanawib (having apprentice), the process of reflecting and rethinking to find the essence of knowledge. Students are suggested to have competence to reflect or actualize the lessons taught. Only by reflection, all matters can be solved. Nashäih li almuta'allim (adjustment), Al-Zarnuji and Ismail (1995) argued that students never held on to their own belief and thought but it was desirable that they placed their trust in God to search for the truth from Him. It meant that an effort of seeking knowledge, prayer and resignation were pedagogical unity that should be held by every knowledge seeker. Mu'taqadätu 'ashrih (developing trust in its period), it was suggested that a learner should not sweep in the evening, mop the floor with fabric, burn onion skin, wear trousers while sitting and wear turban while standing and many others.

Based on the observation, it was found that at the Pesantren Kebon Jambu al-Islami, Buntet and Bendakerep Cirebon was influenced by the book Ta'lim al-Muta'allim. This is to say that the influence was so dominant. All concepts contained in Ta'lim al-Muta'allim were applied in the educational practice at those institutions. Unfortunately, the experience of the concepts implemented was less satisfactory due to textual comprehension of Ta'lim al-Muta'allim. The implementation of education has not functioned properly yet. In the continuously developing and competing age, the activity at those institutions centers upon studying Islamic religious knowledge without any actualization dealing with today's life demand. Whereas, the potential to develop a better educational process is extremely wide open. Educators still hold very infinite authority. Learner is like an empty glass filled by all educators without being able to do much. Moreover, it is deemed a süu al-adab (bad moral) when there was student trying to be critical. The material is concerned with the matters related to the worship in mabdlab (relationship with divinity). It lacks of attention to pupils' future demand later to undergo life in the society, so that the greatness and depth of Ta'lim could not be maximally absorbed by salafi pesantren specifically Kebon Jambu al-Islami, Buntet and Bendakerep Cirebon.

To achieve learning objectives, al-Zarnuji's concept has clearly explained that learning process does not only depend on the educators' role but also learners can play the role as subject in educational process. It means the opportunities to develop pupils' creativity and intellect can be conducted by themselves besides others' role providing assistance to their development which is educators in this case. If examined more deeply, the concept in the Ta'lim has outlined this issue. There are some respects that are explained by Al-Zarnuji and Ismail (1995) related to educators' duties and responsibilities in optimizing learning. They are as follows.

\section{Optimizing learners}

It means being able to develop learners' inward attitude and mentality. This leads to the perfection of attitude and keeping away from the values which bring up negative implication to themselves. Al-Zarnuji and Ismail (1995) asserts that learners should rid themselves from all bad deeds and characters, own sincere and good intention, possess right principles, great soul, intact determination constantly to receive the best respects.

2. Optimizing educators

It implies that to optimize learners to be a good human and to achieve expected learning outcome, educators require to organize certain criteria. Educators should meet the criteria and 
this becomes inevitable because the function attached to them is sufficiently significant. AlNahlawi (1995) concludes that educator has two functions. The first, the function of sanctification. It means that an educator functions as self-cleanser, caretaker, developer, and maintainer of human nature. The second, the function of teaching. It means that an educator has function as conveyor of knowledge and faith to human in order that they can apply all their knowledge in daily life. For educators it is their obligation to spare away their knowledge in order to glorify the knowledge, so that educators are not allowed to make their knowledge as their commodity because it degrades the greatness of knowledge (Al-Dîn, 1985, p. 125)

In this case the reason is actually rational because it shows the causal relationship between science and teaching in their perspective. On the other hand, the causality occurring when it is linked with the context of education today becomes questionable, because the expertise in the field of education teaching becomes the biggest alternative choice in the community as an economic business opportunity. Nevertheless, what can be drawn from the criterion is a sincere attitude of the educators in spreading their knowledge to the learners. In general, these criteria reveal the perfection of educators' characteristics and circumstances by having certain conditions so that they are feasible to be educators as they should be.

The next thing to do is to establish harmonious, loving, and dialogical relationship between learners and educators. This optimization is necessary to achieve sound learning process. Education is an individual issue with a broad demarcation. Therefore, an educator must have harmonious relationship with learners and learners should have a broad opportunity to take the advantage from educators regarding both moral and science (Al-Attas, 1984)

Al-Abrasyi and 'Athiyah (1984) states the creation of a loving personal relationship between educators and learners can be a factor in the success of teaching and learning process. The success of educators is marked by embedded trust and love between educators and learners. When educators love their students and they perceive educators' affection caress, the matters and difficulties in teaching will be easy to overcome and something difficult becomes easier. Students' hatred of a subject is often caused by their hatred of educators teaching the subject. On the contrary, students like a subject due to their enjoyment to the educators teaching the subject.

It is strictly stated that there must be a pedagogical contact in the educational process. This is to say that educators are able to know childhood realm (immaturity) of learners faced and at the same time learners are also able to reach their educators' maturity (Nawawi, 1993). Thus, it is extremely clear that harmonious situation between educators and learners is very significant.

3. Optimizing curriculum

Regarding the curriculum, Al-Zarnuji \& Ismail (1995) has revealed that curriculum is basically divided into two categories namely fard 'ain (compulsory to learn) and fard kifāyah (optional to learn). Qur'an, Hadith, Ushül al-Din, al-Fiqh, and Akbläk (morality) are parts of fardh 'ain curriculum in categorization. Afterwards, the additional subjects are only part of developing primary curriculum (fardu 'ain curriculum). For al-Zarnuji, the important and noble curriculum must be prioritized rather than other curriculum (Al-Kailani, 1986). It means that learners can conduct a study of the above curriculum in a hierarchical manner. Learning any kind of science is permissible as long as it does not abandon the compulsory field of knowledge.

From the above exposure, if the content of material in curriculum developed by Al-Zarnuji \& Ismail (1995) is distinguished, it can be classified into two categories. The first, basic curriculum as reference and paradigm of developing other disciplines. The first curriculum is concretely explained with the religious curriculum. The second, refers to developed curriculum which is beyond religious curriculum. The review applied in the second curriculum is based on basic curriculum so that the basic curriculum provides color to the developed curriculum. What alZarnuji does is actually a must. Knowledge must be affected by religion values, because when it 
is not, it will be evil, pure, and simple. However, if it is affected by religion values, it will be a mercy for mankind (Arifin, 1996).

Therefore, to prioritize the curriculum of the Qur'an from others seems extremely appropriate. Because the Qur'anic curriculum is a distinguishing feature between Islamic education curriculum and other education curriculum (Al-Attas, 1978). The Qur'an is the greatest book as the source of education philosophy and teaching for Muslims. It is a must that Islamic education curriculum is compiled in accordance with the Qur'an as well as hadith as its complement (Ramayulis, 1982).

In term of curriculum, where Qur'an is the source, it seems that it has been convinced by Langgulung (1980). He mentions that dualism in the form of religious and secular knowledge is not characteristic of education based on the Qur'an. Even if it happens, it is caused by sociopolitical factors either from external environment or the internal one. Because the signs (verses) of God's omnipotence are manifested in human and universe aside from those available in the Qur'an, the thing to be preceded is commandment revealed and it is the first category of subject that must exist in education curriculum. The subject must have relationship with Qur'an and Hadith. It is called education with knowledge in the frame of revelation (Hasbullah, 1996). Thus, curriculum which is able to maximize learners is the curriculum which refers to religious dimension, specifically based on the Qur'an and developed in accordance with the needs and circumstances as well as demands of life.

4. Optimizing environment, facility and learning equipment.

These aspects are one of aspects which could not be separated from education. This is to say that facilities and learning equipment are factors that play role in the successful learning activities. In fact, the educational experts generally argue that the improvement of facilities and learning equipment is an inescapable condition to create educational goals (Daradjat, 1996). AlZarnuji \& Ismail (1995) also notes that the thing included in a good facility and learning equipment is the environment itself with social interaction upholding ethical values and complementary relationships. The social interaction concerned is not free social intercourse without clear goals but it is social intercourse with limitation in accordance with one's respective ability. It is known from his statement that learners should not associate with their opposite sex because it will waste the opportunity and dissipate contribution. To have social interaction can be carried out when there is a good value. Moreover, in order to be friend, people should meet the criteria of good moral and upholding religion (Al-Dîn, 1985). Al-Zarnuji \& Ismail (1995) asserts that the people to be a friend are those who own sincerity (al-majd), maintain themselves from bad deed (wara), possess consistency of thinking (shäbib al-thibä' al-mustaqiem). Thus, AlZarnuji \& Ismail (1995) explicitly assumes that association as part of the environment and environment as an infrastructure as well as learning equipment take effect to the educational process. Since environment has a role in creating the successful education, the expected environment must be a conducive environment for learning namely a condition reflecting ethical and religious nuances.

Pesantren is not only required to be a religious institution with Islamic characteristic, but further it is demanded to play more role as principal and strong fort in maintaining and strengthening ethics and moral of nation. The pesantren should not only function as cultural filters, but it should also be able to become initiator and cultural controllers. The educational orientation proposed by the pesantren at a certain time should change or develop in accordance with the demands of era to be responded by the pesantren, because the pesantren which could not respond the demands of the era will gradually be abandoned by the community. Furthermore, this kind of the pesantren is considered incapable to serve students' needs as their competence for their future life in the community. 
The societies still provide great hopes for education in the pesantren. They believe that education in the pesantren is able to serve other nuance to the learners compared to other educational institutions. In addition to providing a deeper understanding of Islam, the pesantren is also considered capable of creating a generation with good morality, which is nowadays not easy to do by other educational institutions. To gain society trust, the pesantren has to push ahead itself to be able to realize the hope of the society, so that it still exists and is able to compete with other educational institutions.

In developing the pattern of Islamic education in the pesantren, the educational system which is considered traditional should improve. In order to improve the quality and expand the educational development in the pesantren, it should take into consideration the following ideas.

a. The pesantren needs to develop more concrete educational objectives, not only relying on the image of its charismatic figures, but also having more orientation to the goals of Islamic education that refers to graduates' future competency standards. The graduates' competency standards demand graduates' profile with qualified skills including attitudes, knowledge, and skills. The graduates' competency standards are used as the guideline for assessment in determining students' graduation from the educational unit. The graduates' competency standard aims to improve intelligence, knowledge, personality, noble character, as well as skills to live independently and carry on further education (Anonimous, 2005). This development is in line with al-Zarnuji's concept stating that learning should be intended: to search for God's willingness, to gain happiness in hereafter, to get rid of ignorance, to develop and preserve Islam, to be grateful for having the grace of mind and healthy body.

b. The pesantren needs to develop the rational thinking applied in its educational system; namely the method of deductive, inductive, critical and causality thinking. It is carried out in order to enhance students' way of thinking from the traditional thinking method to the rational one. Because learning as a process in education. According to (Al-Zarnuji \& Ismail, 1995), learning is to develop all the potential as effectively as possible physically and spiritually to learn, master, appreciate and spread away the knowledge gained either religious or secular knowledge (Anonimous, 2005).

c. Pesantren in this modern era also needs to develop a rational thinking about Islam by teaching the subject matter of philosophy in order that students have a comprehensive perspective on the understanding of religion.

d. The pesantren is obliged to improve students' ability to master the skills, science and technology, so that they are competitive and ready to compete with graduates from other educational institutions to get into working environment after graduating from the pesantren.

e. The pesantren should develop a collectively rational leadership system to improve its educational quality. It can be carried out by establishing the council of kyai. The council of kyai has the authority to appoint and dismiss the leader of the pesantren with certain term of office. for example four or five years. He can be appointed again as long as he still meets the requirements. The limitation of term of office is established in order that the leader of the pesantren beware of carrying out his duties. Because if he commits an offense, he can be dismissed by the council of kyai.

f. The pesantren needs to revise the concept. It does not only have function as students' homestay but also the place to educate students which is optimally utilized in order to form their character. The pesantren should function as a three-center education namely family education, school education, as well as community education. It requires the council of kyai's hard effort, obvious program, firm action, and continuous supervision, so that the function of the pesantren can be achieved maximally. 
g. The pesantren in the future should be able to create learners to be a generation with strong faith, steady piety, high intellect, critical and dynamic mind, noble morality, various skills, and the mastery of science and technology. The alumni of this kind of the pesantren will be able to compete with alumni from other educational institutions, even one step ahead compared with others.

h. The pesantren should maintain simplicity. It should be strived to be maintained and transmitted into formal educational goals by working together. Simplicity It is included in the points of objectives of the pesantren that are not found in formal educational objectives, which have the opportunity to be developed and strived to become one of the goals of formal education. The reason is that simplicity can lead people to own lifestyle as they are, not to force themselves to live beyond their ability, not to be extravagant, but to be easily grateful for the grace received and to have high social awareness to the people requiring their help.

i. The pesantren should cultivate sincerity. It is also the educational goal in the pesantren that is not found in the formal educational objectives. Thus, sincerity is also the educational goal of pesantren that has the opportunity to continuously be developed and pursued to be one of the objectives of formal education because sincerity can educate people to have a qana'ah (to go through life as it is) lifestyle, not to be greedy and to prioritize one's interests from theirs. By owning such lifestyle, people will not take one's rights, seize the things which do not belong to them moreover to grab people's property.

j. The pesantren needs to receive whole-hearted attention from all parties, the Ministry of Religious Affairs, the Ministry of Primary and Secondary Education, the Ministry of Research and Technology, government and those caring about education. By conducting good cooperation between superintendent of pesantren and various parties caring about pesantren, the pesantren whose alumni meet the demands in this current era or in the future can be realized so that it is optimally able to provide its contribution to the national development.

Al-Zarnuji \& Ismail (1995) educational thought mentioned on book Ta'lim al-Muta'allim roughly written in 539 Hijriyah is appropriate with contemporary educational view. It exceeds the contemporary one instead. The book Ta'lim al-Muta'allim not only discusses the basis of learning, strategy of learning and process of learning but also explains integration of knowledge and ethic never touched by contemporary educational figures.

Al-Zarnuji's thoughts are applied a lot by kyais specifically at the Pesantren Kebon Jambu al-Islami, Buntet and Bendakerep Cirebon. From the implementation of book Ta'lim alMuta'allim, those pesantrens have different quality on character (moral), obedience (adherence), respect and simplicity.

\section{Conceptual Model of Ideal Learning at the Pesantren Kebon Jambu al-Islami Babakan Ciwaringin, Buntet and Bendakerep Cirebon}

To complete the learning process at Pesantren Kebon Jambu al-Islami Babakan Ciwaringin, Buntet and Bendakerep Cirebon, it is offered the conceptual model as follow.

1. Idea.

Up to present, the Pesantren Kebon Jambu al-Islami Babakan Ciwaringin, Buntet and Bendakerep Cirebon have not conducted ideal learning yet. Therefore, innovative learning startegy by applying effective learning model is required in order that those institutions can briskly grow up. The effectiveness means there is reasonable compatibility between expectation and result and right conformity between praxis and established standard.

Conceptual models of ideal learning is meant to improve education at pesantren. They must develop more concrette educational goal oriented to competence of graduate's future, improve rational thought in the educational system, increase model of rational thought in Islam by 
teaching philosophy, expand function of pesantren as three-centered-education (family, school and society). Developing student means not only to master religious knowledge but also to have skill and to master science and technology.

2. Implementation of conceptual model of ideal learning. To achieve its success, there are some assumption to fulfil. They are as follows.

a. Human resource.

The human resource must have good and sufficient competence. It is suggested that ustad₹s (moslem scholar) have educational background at pesantren and the formal one at least bachelor degree with specification of appropriate field.

b. Learning operational fund.

In learning process, funding can be categorized into general and specific funding. General funding is expenses allocated to defray educational facilities such as supplying and maintaining facility at pesantren and educational program at pesantren. This fund is gained from students' registration fee and other donation. Meanwhile, specific funding is expenses allocated to realization of learning process such as learning design, learning implementation and learning evaluation. This fund is obtained from students' monthly tuition (syabriab).

c. Facility.

Facility required in the implementation of ideal learning process can utilize available facilities at pesantren. This facility can be categorized into two categories: general facility and specific facility. Facilities included into general facilities are classroom, mosque, learning instrument appropriate with goal and subject matter taught, book reference and students' stationeries. Besides, the kinds of specific facilities are learning media such photo, picture, diagram, sketch, globe, poster, and so on to display the facts relevant to the subject matter and to implement students' comprehension. The environment of pesantren constitutes sufficient laboratory to implement students' comprehension guided by kyai and ustad\%:

d. Good managerial processing.

1) Planning.

Ideal learning should be designed in such away that it is appropriate with the competence of pesantren which has specific content namely not only to be appropriate with orientation of pesantren but also to meet the demand of job and business field. In addition, the implementation of learning should be escorted with innovative programs such as intensification of learning with training material-equipped-modul.

2) Implementation

Learning program at those pesantrens basically has been carried out well. However, it is better to do learning approach flexibly and in a dynamic way using recently popular learning approach namely active, innovative, creative, effective, pleasant, gratifying, and substantive learning.

3) Supervising and Evaluation

Supervising activity should be routinely carried out. Besides, the aspect controlled should be clear. It is not only having ordinary visit. Supervising is not only to control or evaluate implementation of learning but also to check individuals' work including relationship among them.

All the explanation about the conceptual model of ideal learning at pesantren can be summarized at Figure 2. 


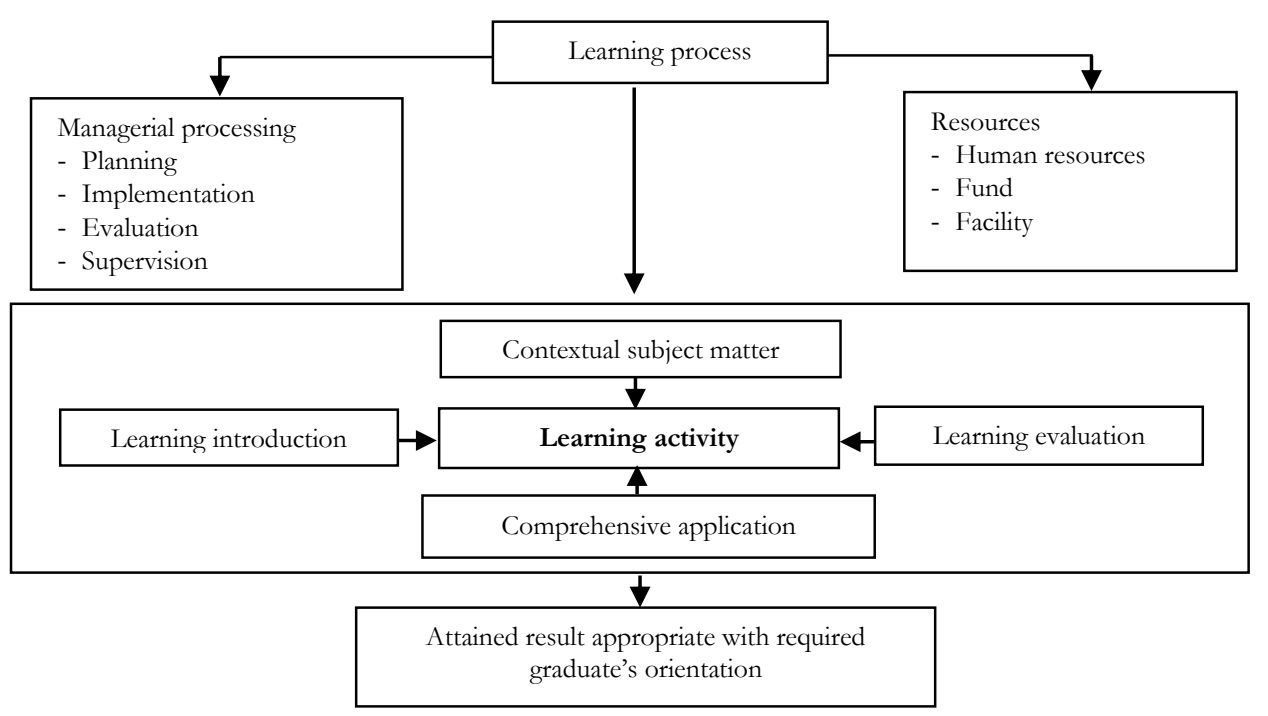

Figure 2. The Conceptual Model of Ideal Learning at Pesantren.

\section{CONCLUSION}

Conceptual models of ideal learning proposed to increase the quality of education at pesantren. This can be done by identifying the class, developing more concrete learning goal oriented to the competence of graduate's future, setting clear program with subject matter adjusted with students' need, developing rational pattern of thought in Islam by teaching philosophy. The educational process which promotes collective, pragmatic and compromising rational pattern will be better if the learning approach is applied in a dynamically and flexibly manner. It can be implemented by using recent popular learning approach namely active, innovative, creative, effective, pleasant, gratifying, and substantive learning, expanding function of pesantren as threecentered-education (family, school and society). Periodic and continuous evaluation can improve students' mastery of religious knowledge as well as science and technology also students' skill. To support its success, some factors should be met. They are human resource with good and sufficient competence, sufficient learning operational fund, good facility and good managerial processing covering planning, implementation, evaluation and supervising. In addition to this, the researcher provides some recommendations to the Pesantren Kebon Jambu al-Islami Babakan Ciwaringin, Buntet and Bendakerep Cirebon as follows: 1) it is required that those institutions develop learning process and combine salafiyah and khalafiyah model of learning implemented on their educational system so that students can be empowered to have skills on technology that is socially and economically useful; 2) it is needed that those institutions maintain an open mind and modify their educational system as learning method that can be received by all elements of the society so that educational system at those pesantrens becomes extremely inclusive; 3) it is necessary that those institutions carry out empowering, establishing and developing educators' knowledge by financing their study from bachelor degree, master degree up to doctoral degree; 4) it is requisite that those institutions develop their economy by establishing business sectors being able to increase ustadzs' prosperity so that it can make opportunity to develop organization especially developing educational institution to fulfill the demand of society either religious education or Islamic secular education.

\section{BIBLIOGRAPHY}

Akhyar, Y. (2008). Metode belajar dalam kitab Ta'lim al-Muta'allim Thariqat At-Ta'allum (telaah pemikiran tarbiyah az-Zarnuji). Al-Fikra: Jurnal Ilmiah Keislaman, 7(2), 311-342. Retrieved from http://ejournal.uin-suska.ac.id/index.php/ al-fikra/article/view/3796/2337 
Al-Abrasyi, M. 'Athiyah. (1984). Al-Tarbiyah al-Islämiyàt wa falsafatubā. Beirut: Dar al-Fikr.

Al-Attas, S. M. N. (1978). Islam and secularism. Kuala Lumpur: Muslim Youth Movement of Malaysia (ABIM).

Al-Attas, S. M. N. (1984). Aim and objectives of Islamic education. Kuala Lumpur: Muslim Youth Movement of Malaysia (ABIM).

Al-Dīn, 'Abd Amīr Syams. (1985). Al-Fiker al-tarbawy "inda Ibn al-Muqaffa", al-Jāhiz, 'Abd al-Hamid al-Kätib. Beirut: Dār al-Iqra'.

Al-Kailani, M. A. (1986). Al-Fikru al-tarbawi ’inda Ibnu Taimiyah. Madinah: Maktabah Dār alTurats.

Al-Nahlawi, A. al-R. (1995). Ushül al-tarbiyah al-Islämiyah wa asälibibā translated by Shibabuddin, pendidikan Islam di rumah, sekolah, dan masyarakat. Jakarta: Gema Insani Press.

Al-Zarnuji, \& Bin Ismail, S. I. (1995). Syarah Ta'lim al-Muta'alim. Kudus: Menara Kudus.

Anonimous. (2005). Standar nasional pendidikan PP RI No.19 tahun 2005 tentang standar nasional pendidikan. Jakarta: LEKDIS.

Arifin, H. M. (1996). Filsafat pendidikan Islam. Jakarta: BumiAksara.

Daradjat, Z. (1996). Kesehatan mental, peranannya dalam pendidikan dan pengajaran. Jakarta: IAIN Syarif Hidayatullah.

Hasbullah. (1996). Kapita selekta pendidikan Islam. Bandung: Rosda.

Huda, M., Jasmi, K. A., Mustari, I., Basiron, B., \& Sabani, N. (2017). Understanding divine pedagogy in teacher education: Insights from al-Zarnuji's Ta'lim Al-Muta'Allim. The Social Sciences, 12(4), 674-679. Retrieved from https://goo.gl/So9eCV

Huda, M., \& Kartanegara, M. (2015a). Aim formulation of education: An analysis of the book Ta'lim al-Muta'allim. International Journal of Humanities and Social Science, 5(2), 143-149. Retrieved from https://goo.gl/yvNo4r

Huda, M., \& Kartanegara, M. (2015b). Distinctive feature of al-Zarnūjī̀s ideas: A philosophical inquiry into the book Ta'līm al-Muta'allim. American International Journal of Contemporary Research, 5(2), 171-177. Retrieved from https://goo.gl/YMBK1j

Langgulung, H. (1980). Beberapa pemikiran tentang pendidikan Islam. Bandung: PT. Al Ma'arif.

Miftahuddin. (2006). Konsep profil guru dan siswa (mengenal pemikiran Al-Zarnuji "LimalMuta"allim dan relevansinya). Cakrawala Pendidikan, 25(2), 247-267. Retrieved from https://goo.gl/RKS1MD

Nakosteen, M. (1964). History of Islamic origins of Western education A.D. 800-1350. Boulder: University of Colorado Press.

Nawawi, H. (1993). Pendidikan dalam Islam. Surabaya: Al-Ikhlas.

Ramayulis. (1982). Didaktik metodik. Fakultas Tarbiyah IAIN Imam Bonjol.

Ummah, Y. C., \& Wajdi, M. B. N. (2016). Dismantling paradigm book Ta'limul Muta'alim. Journal of Education, 1(2), 1-10. Retrieved from https://goo.gl/hJFkwN 